\title{
Estimation of the synaptic conductance in a McKean-model neuron
}

\author{
Antoni Guillamon ${ }^{1}$, Rafel Prohens ${ }^{2}$, Antonio E Teruel ${ }^{2}$, Catalina Vich ${ }^{2 *}$ \\ From 24th Annual Computational Neuroscience Meeting: CNS*2015 \\ Prague, Czech Republic. 18-23 July 2015
}

Estimating the synaptic conductances impinging on a single neuron directly from its membrane potential is one of the open problems to be solved in order to understand the flow of information in the brain. Despite the existence of some computational strategies that give circumstantial solutions ([1-3] for instance), they all present the inconvenience that the estimation can only be done in subthreshold activity regimes. The main constraint to provide strategies for the oscillatory regimes is related to the nonlinearity of the input-output curve and the difficulty to compute it. In experimental studies it is hard to obtain these strategies and, moreover, there are no theoretical indications of how to deal with this inverse non-linear problem. In this work, we aim at giving a first proof of concept to address the estimation of synaptic conductances when the neuron is spiking. For this purpose, we use a simplified model of neuronal activity, namely a piecewise linear version of the Fitzhugh-Nagumo model, the McKean model ([4], among others), which allows an exact knowledge of the nonlinear $\mathrm{f}-\mathrm{I}$ curve by means of standard techniques of non-smooth dynamical systems. As a first step, we are able to infer a steady synaptic conductance from the cell's oscillatory activity. As shown in Figure 1, the model shows the relative errors of the conductances of order $\mathrm{C}$, where $\mathrm{C}$ is the membrane capacitance $(\mathrm{C}<<1)$,
A.

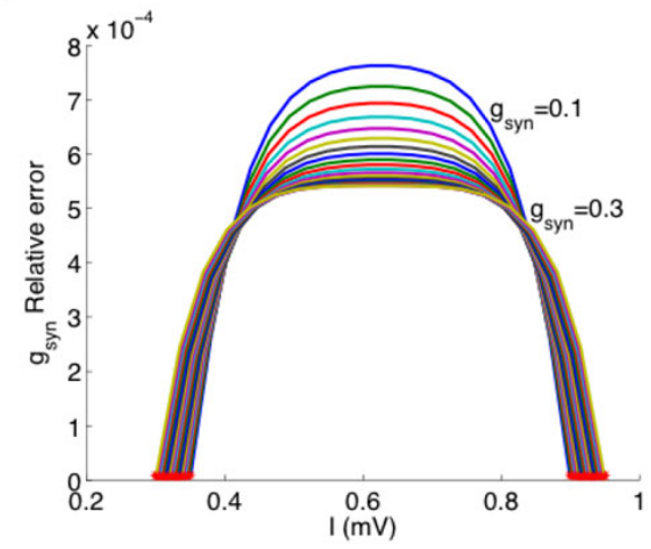

B.

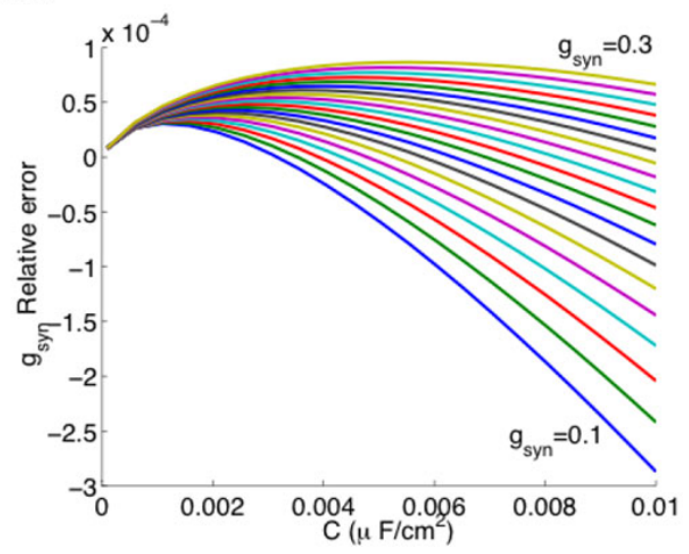

Figure 1 Goodness of fit of the synaptic conductance parameter. Panel A represents the relative error versus the applied current for a fixed value of $C=10^{-4}$. Red points represent the values of $I_{1}$ (left points) and $I_{2}$ (right points) for each $g_{\text {syn. }}$. Panel $B$ represents the relative error versus the membrane capacitance for a fixed value of $I_{1} I_{1}+10^{-3}$. In both panels, the different color traces correspond to different values of $g_{\text {syn }}$ equally spaced from 0.1 to 0.3 . The rest of parameters are fixed as $\boldsymbol{a}=0.25, v_{0}=0, w_{0}=0, \gamma=0.5, v_{\text {syn }}=0.25+\boldsymbol{a} / 2$.

${ }^{2}$ Dept. of Mathematics and Computer Science, Universitat de les Illes Balears,

07122, Palma, Spain

Full list of author information is available at the end of the article

() BioMed Central

(C) 2015 Guillamon et al. This is an Open Access article distributed under the terms of the Creative Commons Attribution License (http://creativecommons.org/licenses/by/4.0), which permits unrestricted use, distribution, and reproduction in any medium, provided the original work is properly cited. The Creative Commons Public Domain Dedication waiver (http://creativecommons.org/ publicdomain/zero/1.0/) applies to the data made available in this article, unless otherwise stated. 
notably improving the errors obtained using filtering techniques on the membrane potential plus linear estimations, see numerical tests performed in [5].

\section{Authors' details}

1Dept. of Applied Mathematics I, EPSEB, Universitat Politècnica de Catalunya, 08028 Barcelona, Spain. ${ }^{2}$ Dept. of Mathematics and Computer Science,

Universitat de les Illes Balears, 07122, Palma, Spain.

Published: 18 December 2015

\section{References}

1. Bédard C, Béhuret S, Deleuze C, Bal T, Destexhe A: Oversampling method to extract excitatory and inhibitory conductances from single-trial membrane potential recordings. Journal of Neuroscience Methods 2012, 210:3-14.

2. Lankarany M, Zhu W-P, Swamy S, Toyoizumi T: Inferring trial-to-trial excitatory and inhibitory synaptic inputs from membrane potential using Gaussian mixture Kalman filtering. Frontiers in Computational Neuroscience 2013, 7(109).

3. Rudolph M, Piwkowska Z, Badoual M, Bal T, Destexhe A: A method to estimate synaptic conductances from membrane potential fluctuations. Journal of Neurophysiology 2004, 91(6):2884-2896.

4. Coombes S: Neuronal networks with gap junctions: A study of piecewise linear planar neuron models. SIAM Journal of Applied Dynamical Systems 2008, 7(3):1101-1129.

5. Guillamon A, McLaughlin DW, Rinzel J: Estimation of synaptic conductances. Journal of Physiology-Paris 2006, 100(1-3):31-42.

doi:10.1186/1471-2202-16-S1-P251

Cite this article as: Guillamon et al:: Estimation of the synaptic conductance in a McKean-model neuron. BMC Neuroscience 2015 16(Suppl 1):P251.

\section{Submit your next manuscript to BioMed Central} and take full advantage of:

- Convenient online submission

- Thorough peer review

- No space constraints or color figure charges

- Immediate publication on acceptance

- Inclusion in PubMed, CAS, Scopus and Google Scholar

- Research which is freely available for redistribution

Submit your manuscript at www.biomedcentral.com/submit
Ciomed Central 